\title{
Pre-Mesozoic Palinspastic Reconstruction of the Eastern Great Basin (Western United States)
}

\author{
Marjorie Levy and Nicholas Christie-Blick
}

The Great Basin of the western United States has proven important for studies of Proterozoic and Paleozoic geology [ 2500 to 245 million years ago (Ma)] and has been central to the development of ideas about the mechanics of crustal shortening and extension. An understanding of the deformational history of this region during Mesozoic and Cenozoic time (245 $\mathrm{Ma}$ to the present) is required for palinspastic reconstruction of now isolated exposures of older geology in order to place these in an appropriate regional geographic context. Considerable advances in unraveling both the crustal shortening that took place during Mesozoic to early Cenozoic time (especially from about 150 to $50 \mathrm{Ma}$ ) and the extension of the past 37 million years have shown that earlier reconstructions need to be revised significantly. A new reconstruction is developed for rocks of middle Proterozoic to Early Cambrian age based on evidence that total shortening by generally east-vergent thrusts and folds was at least 104 to 135 kilometers and that the Great Basin as a whole accommodated $\sim 250$ kilometers of extension in the direction $287^{\circ} \pm 12^{\circ}$ between the Colorado Plateau and the Sierra Nevada. Extension is assumed to be equivalent at all latitudes because available paleomagnetic evidence suggests that the Sierra Nevada experienced little or no rotation with respect to the extension direction since the late Mesozoic. An estimate of the uncertainty in the amount of extension obtained from geological and paleomagnetic uncertainties increases northward from \pm 56 kilometers at $36^{\circ} 30^{\prime} \mathrm{N}$ to ${ }_{-87}^{+108}$ kilometers at $40^{\circ} \mathrm{N}$. On the basis of the reconstruction, the original width of the preserved part of the late Proterozoic and Early Cambrian basin was about 150 to 300 kilometers, about 60 percent of the present width, and the basin was oriented slightly more north-south with respect to present-day coordinates.

$\mathrm{T}$ he Great Basin of the western United States (Fig. 1) is a classic area for geological research both for the quality of exposure and diversity of geology preserved and as a source of ideas concerning fundamental geological processes. For example, it was in this region that miogeoclinal rocks of late Proterozoic and Early Paleozoic age were early interpreted as an ancient passive continental margin $(1,2)$, an interpretation that has

The authors are at the Department of Geological Sciences and Lamont-Doherty Geological Observatory of Columbia University, Palisades, NY 10964. been refined recently through the use of new quantitative techniques of subsidence analysis (3-5). The late Devonian and early Mississippian Antler orogeny of central Nevada is a classic example of the emplacement of a deep-water accretionary prism onto the edge of a continent $(2,6-8)$. The Mesozoic to early Cenozoic Cordilleran fold and thrust belt, a segment of which is located between western Wyoming and eastern California along the eastern side of the Great Basin (Figs. 1 and 2), is among the best studied thin-skinned orogens on Earth (9-13). The Great Basin itself, an area of pronounced extension in mid- to late Cenozoic time, has long been central to the development of paradigms about mechanisms of crustal extension (14-22).

Beyond the insights gained about crustal deformation, an understanding of the Mesozoic and Cenozoic deformational history is essential for undertaking a regional palinspastic reconstruction (23) and hence for the identification and interpretation of broad preMesozoic patterns. Fifteen years have passed since the most recent publication of a regional reconstruction of the Great Basin (2). During that time, the area has been the subject of numerous structural and stratigraphic studies, and a good deal of new subsurface data has become available [for example, (24-27)]. In this article we use these data to develop a new palinspastic reconstruction for pre-Mesozoic time. The reconstruction differs substantially from earlier versions [for example, $(2,28)]$ because we incorporate considerably larger estimates for both Cenozoic extension and Mesozoic to early Cenozoic crustal shortening and modify the way in which deformation is partitioned according to structural position and geographic location (Table 1). Our reconstruction also differs from that of Stewart and Poole (2) because we exclude the effects of the Antler orogeny and younger Paleozoic deformational events. Our reconstruction is specific for sedimentary rocks of middle Proterozoic through Early Cambrian age [ 1600 to about 535 million years ago $(\mathrm{Ma})(29,30)]$, an interval of geological history that, with few exceptions, is not represented in the Paleozoic orogens of the western United States.

\section{Regional Setting}

The evolution of the Great Basin from the late Proterozoic to the present can be subdivided into three phases: (i) Late Proterozoic to mid-Paleozoic time (from $\sim 800 \mathrm{Ma}$ to $\sim 375 \mathrm{Ma}$ ) was characterized by intracontinental extension and the development of a passive continental margin $(1,2,5,31)$. Marine and nonmarine predominantly siliciclastic sedimentary rocks and volcanic rocks of late Proterozoic to Early Cambrian age form the lower part of a miogeoclinal wedge and generally thicken westward from $<150 \mathrm{~m}$ along the eastern margin of the Great Basin to $>6000 \mathrm{~m}(2,14)$. The upper part of this wedge consists for the most part of peritidal 
carbonate rocks and mudstones of Middle Cambrian to Devonian age and is as much as $5000 \mathrm{~m}$ thick. The entire miogeoclinal succession rests unconformably on crystalline basement of Archean to early middle Proterozoic age and in places on relatively unmetamorphosed sedimentary rocks of middle Proterozoic age $(5,32)$. (ii) The late Devonian through early Eocene ( $\sim 375$ to $50 \mathrm{Ma})$ was a time of crustal shortening, accretion of exotic or suspect terranes of varying affinity, and subduction-related magmatism $(2,7,8,11,13$, 33). Paleozoic deformational events were localized in central and western Nevada and for the most part did not affect the eastern Great Basin. However, as much as $3500 \mathrm{~m}$ of Mississippian sedimentary rocks accumulated in a foreland basin adjacent to the Antler orogen in eastern Nevada (7). Nearly 8000 m of Pennsylvanian and Permian rocks were deposited in northern Utah probably as a result of continental collision at the southern margin of North America (34, 35). Evidence for Mesozoic and early Cenozoic deformation is best developed in the eastern and southern Great Basin [Cordilleran fold and thrust belt in Fig. 1 $(11,13)$ ] but is known also from the "hinterland" of this belt [west of the shaded area in Fig. $1(21,36,37)]$. (iii) In mid- to late Cenozoic time (about $37 \mathrm{Ma}$ to the present), the entire region between the Colorado Plateau and the Sierra Nevada was subject to lithospheric extension and widespread magmatism $(17,19,22,38,39)$.

The western limit of Precambrian crystalline basement is thought to be delineated approximately by the $I_{\mathrm{Sr}}=0.706(40)$ isopleth for Mesozoic and Cenozoic igneous rocks, hereafter referred to as the 0.706 line [Fig. $1(8,41,42)]$. An alternative view, that the edge of the Precambrian basement may correspond approximately with the $I_{\mathrm{Sr}}=0.708$ isopleth, located as much as $100 \mathrm{~km}$ farther east (43), appears to be inconsistent with the distribution of Proterozoic and Lower Cambrian sedimentary rocks near the 0.706 line (Fig. 2). Available evidence indicates that at least some of these rocks predate the development of the Paleozoic passive continental margin and, if this is correct, must have accumulated on continental crust $(3,5,31)$. Indeed, rocks of probable latest Proterozoic age are present in the Bull Run Mountains [BR in Fig. 2 (44)] at least $40 \mathrm{~km}$ north and west of the recently refined position of the 0.706 line in northern Nevada and far outboard of the 0.708 line $(8,42)$.

Significant north-south variations are evident in the Mesozoic and Cenozoic tectonic and igneous framework of the Great Basin (Fig. 1). In northern Utah, Idaho, and Wyoming, late Mesozoic to early Cenozoic crustal shortening is localized for the most part in the Paleozoic platform east of the late Proterozoic to early Paleozoic miogeoclinal wedge, and is associated with a broad foreland basin. In southern Utah, southern Nevada, and adjacent California, much of the shortening is in the miogeocline, and foreland-basin sedimentary rocks are conspicuously thin to absent. The inner margin of the Mesozoic magmatic arc is located west of the northern segment of the fold and

Fig. 1. Mesozoic and Cenozoic tectonic and igneous framework of the Great Basin of the western United States [from $(8,19,20,41,42,50$, 55)]. The $I_{\mathrm{Sr}}=0.706$ isopleth is thought to delineate approximately the western limit of Precambrian crystalline basement and is included for reference on each figure. The patterned area indicates the frontal part of the Cordilleran fold and thrust belt. thrust belt but lies within the southern segment. The mid- to lateCenozoic Great Basin cuts across both the miogeocline and the fold and thrust belt, as well as the 0.706 line. Highly extended regions [including metamorphic core complexes (18)] are located west of the fold and thrust belt in the north but well within and even east of this belt in the south. If extension was localized in areas of overthickened crust $(39,45)$, the locus of thickening must have varied regionally according to the geometry of structures at depth and the predeformation thickness of the crust $(5,22)$.

\section{Mesozoic and Early Cenozoic Shortening}

The Cordilleran fold and thrust belt is a curvilinear belt, approximately 100 to $200 \mathrm{~km}$ wide, that is discontinuously exposed from Alaska to Mexico $(9-13,46,47)$. Along the eastern margin of the Great Basin, deformation occurred mainly during Mesozoic to early Cenozoic time (especially from $\sim 150$ to $50 \mathrm{Ma}$ ) with the locus of deformation migrating progressively toward the east $(9,11,13,24$, 48-53). Thrusting was mostly to the east, and overall crustal shortening is estimated to have been at least 104 to $135 \mathrm{~km}$ (Table 1). Allochthonous rocks are mainly of middle Proterozoic through Paleozoic age, but in places thrust faults can be seen to cut westward into underlying crystalline basement, particularly in northern Utah and eastern California $(11,25,54)$. In the eastern part of the belt, especially in southern Wyoming and central Utah, thrust ramps rise through Paleozoic platformal cover into the Mesozoic strata and deform early deposits of the coeval foreland basin $(25,52,54,55)$.

The western boundary of the fold and thrust belt shown in Fig. 1 is somewhat arbitrary. Available geochronology indicates that in the hinterland, Proterozoic and lower Paleozoic rocks were widely subject to thrusting, penetrative deformation, and metamorphism $(21,36,37)$. In some places, younger Paleozoic rocks were also involved in thrusting $(8,56,57)$, although on a regional scale they were little deformed during Mesozoic time $(16,20)$. Limited evidence suggests that the amount of shortening in the sedimentary

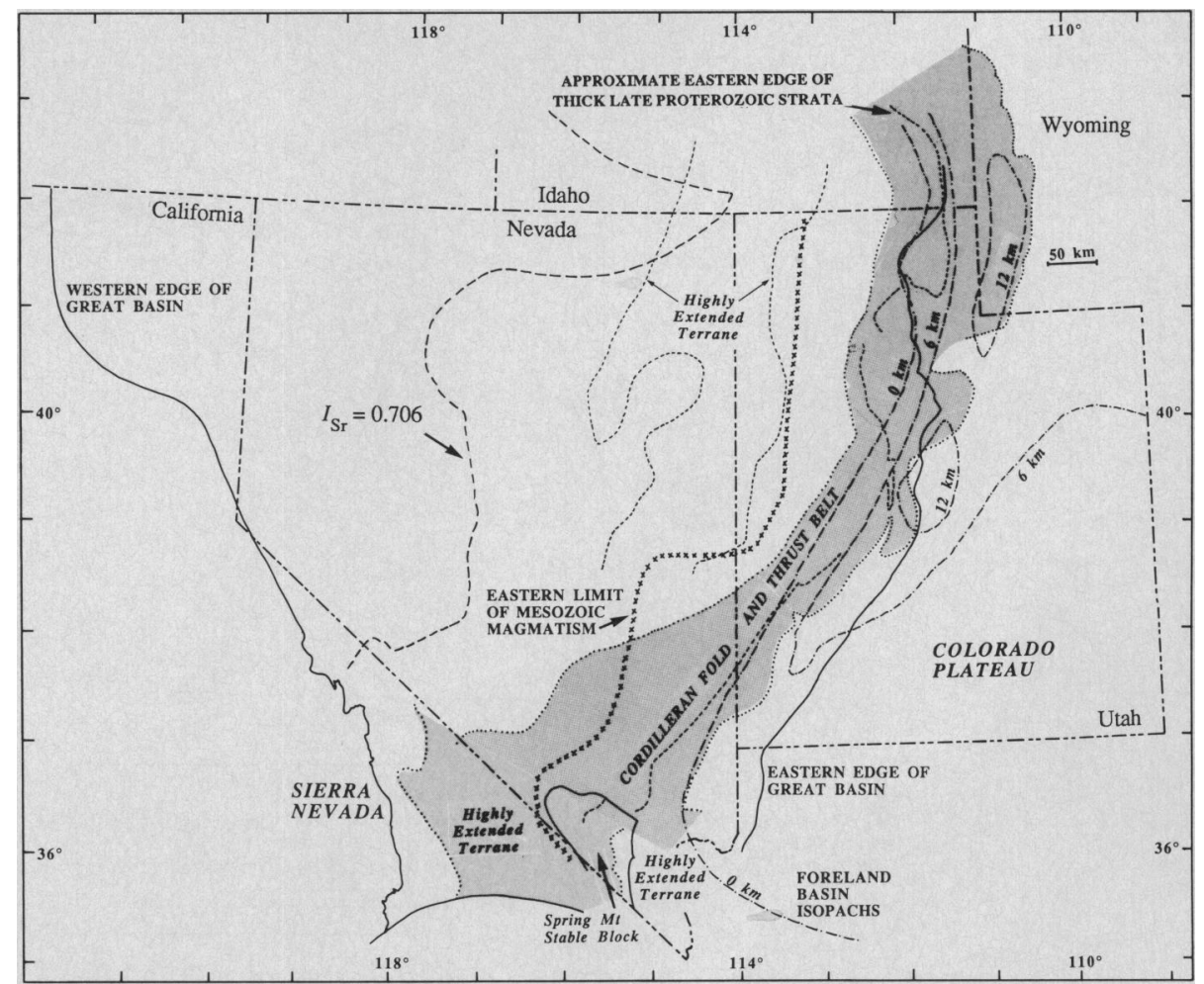


cover of the hinterland was small in comparison with that taken up by the frontal part of the fold and thrust belt $(8,57)$.

The timing of thrusting is best constrained in the Idaho-Wyoming salient where cross-cutting and overlapping relations of the younger thrusts and synorogenic conglomerates associated with the older thrusts indicate that thrusting began in latest Jurassic to early Cretaceous time and continued through the early Eocene $(9,13,24$, $48,50-52)$. In central Utah, ages of individual thrust faults are not well-constrained, but subsidence analysis of the foreland-basin sedimentary rocks suggests that faulting began in mid-Cretaceous time (58). In the southern Great Basin, geochronology of plutons and synorogenic volcaniclastic rocks indicates that some thrust faults were active as early as Triassic time $(49,53)$ and that deformation continued in this region until the late Cretaceous $(11,49,59)$.

Structural relations of thrust faults from Wyoming to eastern California are not universally agreed upon because of discontinuous exposure, uncertainty in the timing of deformation, and along-strike changes in fault geometry and in the direction and magnitude of shortening. Individual faults probably do not persist laterally along the entire belt. More likely they form a relay pattern in which shortening is taken up by different structures in different parts of the belt, as is the case in southern Canada (12). However, thrust plates can be compared on the basis of stratigraphy and structural position, as indicated by connections in Fig. 2. The easternmost thrust sheets that contain thick successions of late Proterozoic age at the present level of exposure are the Paris-Willard, Sheeprock, Canyon Range, Wah Wah-Frisco, Gass Peak, and Wheeler Pass plates [Fig. 2 (2, 10, $13,59,60)]$. Structurally lower and possibly related thrusts are the Tintic Valley, Pavant, Muddy Mountains, and Keystone faults. The Absaroka and Charleston-Nebo thrust faults, still lower structurally, may connect at depth and are present only north of the Leamington tear fault [Fig. $2(13,54)]$.

In eastern California and southern Nevada, individual thrust faults are offset by Cenozoic extensional and strike-slip faults and are repeated in map view. Wernicke et al. (22) and Corbett et al. (53) have suggested correlations on the basis of stratigraphy and stratigraphic separation, structural geometry, kinematic indicators, and limited age control. Such correlations are important for the reconstruction of Cenozoic deformation but details are controversial.

\section{Cenozoic Extension}

The Great Basin is a broad region of evenly spaced, northtrending tilted horsts separated by partially filled half-graben. The region is characterized by thinned crust, high elevation, high heat flow, episodic magmatism, and low seismic velocities in the upper mantle $(17,19)$. Crustal extension was accommodated by both highand low-angle normal faults and, especially in the southern Great Basin, by several prominent strike-slip faults such as the Northern Death Valley-Furnace Creek fault zone, Las Vegas Valley shear zone, and Lake Meade fault system (Fig. 2). Faults such as these account for part of the right shear along the Pacific-North America plate boundary, and they act as transfer faults separating areas characterized by different amounts of extension $(22,61,62)$.

Overall extension across the Great Basin is estimated as about 247 $\mathrm{km}$ in a west-northwest direction (22). It is thought to have begun in latest Eocene to earliest Oligocene time (19-21, 37-39) and continues today. In the northern Great Basin, the earliest phase of extension (37 to $\sim 10 \mathrm{Ma}$ ) was restricted to a relatively narrow region of high strain in eastern Nevada, western Utah, and southern Idaho and was associated with intermediate to silicic calcalkaline volcanism $(17,19-21,37,38)$. Later extension, associated with basaltic and rhyolitic volcanism, was distributed over a much broader region of generally lower strain (17, $19,38)$, although evidence for relatively large amounts of extension at specific localities since $10 \mathrm{Ma}$ indicates that extensional behavior cannot be partitioned strictly ac-

Fig. 2. Location map of prominent faults in and immediately east of the Great Basin, and the distribution of middle Proterozoic to Lower Cambrian outcrops [shown in black; from (100)]. These rocks are used to illustrate the palinspastic reconstruction in the maps that follow. Faults: $A$, Absaroka; $C$, Canyon Range; $C-N$, CharlestonNebo; $\mathrm{Ch}$, Chicago Pass; $\mathrm{Cl}$, Clery; $\mathrm{Cr}$, Crawford; $F C$, Northern Death Valley-Furnace Creek fault zone; GP, Gass Peak; $H$, Hogsback; $K$, Keystone; $L$, Lemoigne; $L C$, Last Chance; $L M$, Lake Meade fault system; $L T F$, Leamington tear fault; $L V$, Las Vegas Valley shear zone; $M$, Meade; $M C$, Marble Canyon; $M i$, Midas; $M M$, Muddy Mountains; $P$, Putnam-Paris; $\mathrm{Pa}$, Pavant; $P_{n}$, Panamint; Sh, Sheeprock; SP, Schwaub Peak; $T V$, Tintic Valley; $W$, Willard; $W-F$, Wah WahFrisco; $W a$, Wasatch; Wh, Wheeler Pass; Wi, Winters Pass. Ranges: Al, Albion; BP, Black Pine; BR, Bull Run; CC, Cherry Creek; E, Egan; GC, Grouse Creek; I, Inyo; KR, Kingston; P, Panamint; RR, Raft River; SC, Schell Creek; Sn, Snake. Other localities mentioned in the text: DV, Death Valley; GSL, Great Salt Lake; SLC, Salt Lake City. 
cording to age (39). In the southern Great Basin, extension began at least as early as 25 $\mathrm{Ma}$, with most of it taking place during the past 15 million years $(22,38,63)$. The Death Valley and Las Vegas Valley regions on either side of the Spring Mountains stable block are both highly extended areas [Fig. l $(61,64,65)$ ].

A characteristic feature of many of the highly extended areas is the presence of metamorphic core complexes, in which ductilely deformed lower plate rocks are structurally overlain by brittlely deformed upper plate rocks, commonly with evidence for large displacement on an intervening detachment fault (18). Examples of core complexes in areas of middle Proterozoic to Lower Cambrian outcrops are the Albion Range in southern Idaho, the Snake Range in eastern Nevada, and the northern Panamint Range in eastern California ( $\mathrm{Al}, \mathrm{Sn}$, and $P$ in Fig. 2).

\section{Palinspastic Reconstruction}

Structural interpretations, seismic and borehole data, stratigraphic data from outcrop, and paleomagnetic constraints on the Mesozoic orientation of the Sierra Nevada have been used to develop a palinspastic reconstruction of the eastern Great Basin (Fig. 3). The primary input for the reconstruction consists of five regional transects of the fold and thrust belt (Table 1), together with syntheses of the extensional development of parts of the Great Basin by Gans and Miller (20) and Wernicke et al. (22). The reconstruction is presented as a working hypothesis, subject to modification and testing. Inevitably, choices need to be made between conflicting interpretations of existing data, and simplifying assumptions are required to extend available constraints to a regional scale. All of this involves several potential sources of error, which are evaluated in the next section.

Fig. 3. (A) Palinspastic reconstruction of mid- to late Cenozoic extension and Mesozoic to early Cenozoic shortening with respect to a fixed Colorado Plateau and fixed state boundaries. The reconstruction is illustrated for selected examples of middle Proterozoic to Lower Cambrian outcrops. Extension is restored along the solid line from the outcrop in a general eastward direction (east-northeast to east-southeast). Then, shortening is removed along the dashed vector from the end of the solid line and toward the west. The restored position of a given outcrop is at the head of the dashed vector. (B) Final reconstruction of all middle Proterozoic to Lower Cambrian outcrops. Apparent overlap of rocks in the highly extended regions of eastern Nevada and the southern Great Basin is an artifact. Overlap of individual horizons is not necessarily implied.
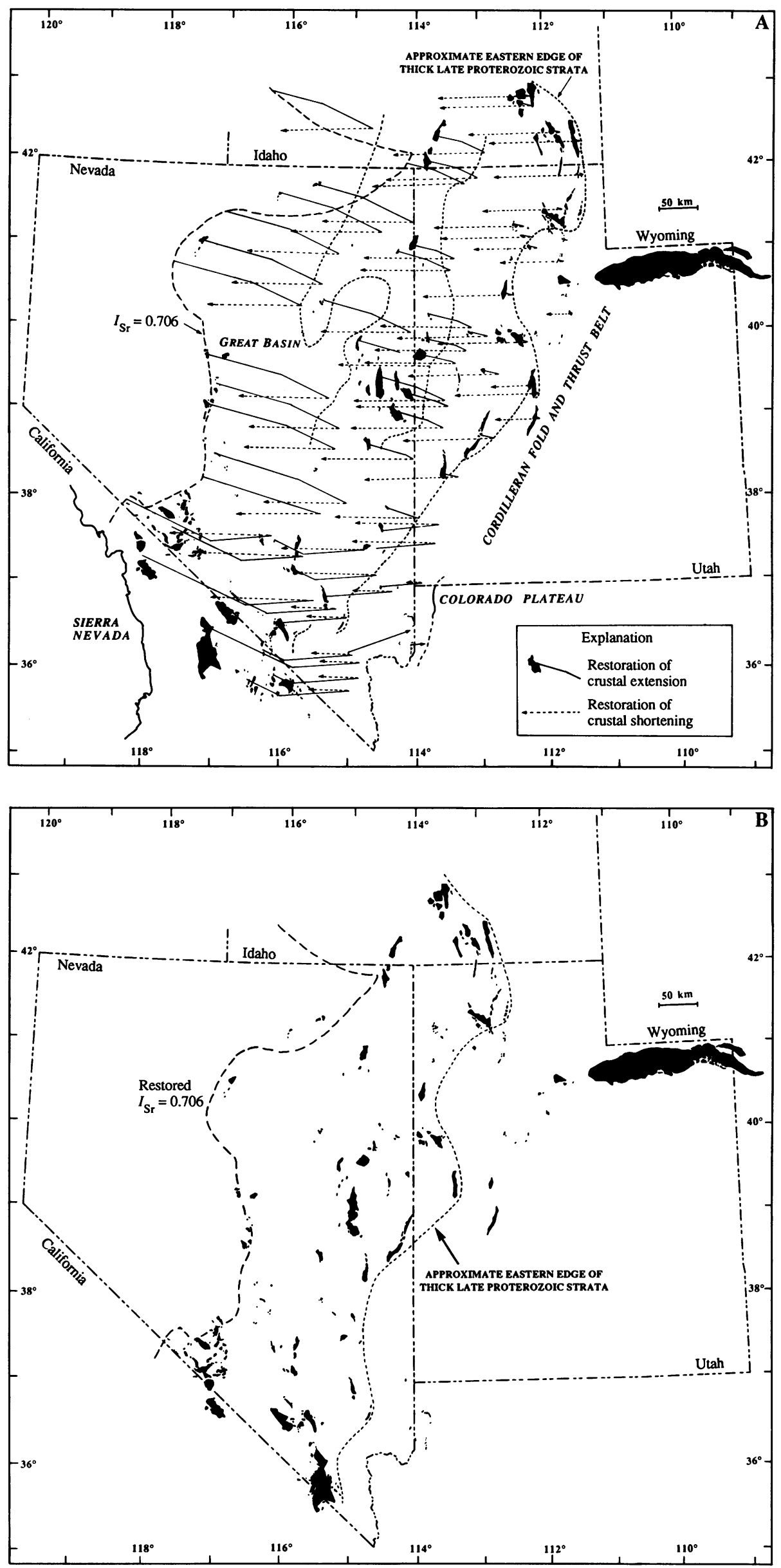
Reconstruction of Cenozoic extension. The magnitude of Cenozoic extension is best constrained in the southern Great Basin where abundant geological markers can be correlated across faults. These correlations indicate that overall extension of $247 \mathrm{~km}$ in the direction $287^{\circ}$ needs to be restored [Fig. 3 (22)]. In detail, extension is partitioned into two segments, both of which are characterized by high strain. Available data suggest that the Death Valley region, to the west of the medial unextended Spring Mountains block (Fig. 1), experienced a total of $\sim 150 \mathrm{~km}$ of extension oriented westnorthwest with respect to the Colorado Plateau, whereas the Las Vegas Valley region to the east of the Spring Mountains block experienced 90 to $100 \mathrm{~km}$ of west-southwest-directed extension [Fig. 3 (22)]. This partitioning is consistent with earlier estimates of $80 \mathrm{~km}$ of right slip on the Northern Death Valley-Furnace Creek fault zone (64), >40 to $65 \mathrm{~km}$ of right slip on the Las Vegas Valley shear zone (66), and a minimum of $65 \mathrm{~km}$ of left slip on the Lake Mead fault system $(65,67)$.

The northern Great Basin differs from the Death Valley and Las

Table 1. Estimates of minimum east-west shortening associated with thrust faults along five transects in the eastern Great Basin from Wyoming to eastern California.

\begin{tabular}{|c|c|c|}
\hline Thrust fault & $\begin{array}{l}\text { Shortening } \\
\quad(\mathrm{km})\end{array}$ & References \\
\hline $\left.\begin{array}{l}\text { 1. Southeastern Idaho } \\
\text { Hogsback } \\
\text { Absaroka } \\
\text { Meade } \\
\text { Putnam-Paris }\end{array}\right\}$ & $\begin{array}{c}121 \text { total } \\
51 \\
70\end{array}$ & $\begin{array}{c}(24,73) \\
(24)\end{array}$ \\
\hline $\left.\begin{array}{l}\text { 2. Northern Utah } \\
\text { Hogsback } \\
\text { Absaroka } \\
\text { Crawford } \\
\text { Willard }\end{array}\right\}$ & $\begin{array}{l}104 \text { total } \\
53\end{array}$ & $\begin{array}{c}(24,73) \\
(24) \\
(24,96)\end{array}$ \\
\hline $\begin{array}{l}\text { 3. Salt Lake City Area } \\
\text { Hogsback } \\
\text { Absaroka }\} \\
\text { Ogden, Weber, Taylor } \\
\text { Basement imbricates } \\
\text { Willard }\end{array}$ & $\begin{array}{l}120 \text { total } \\
53 \\
12 \\
20 \\
35\end{array}$ & $\begin{array}{c}(24) \\
(24) \\
(78) \\
(24,25,54) \\
(74,96)\end{array}$ \\
\hline $\begin{array}{l}\text { 4. Central Utah, northern segment } \\
\text { Charleston-Nebo } \\
\text { Midas } \\
\text { Tintic Valley } \\
\text { Sheeprock } \\
\text { Central Utah, southern segment } \\
\text { Salina } \\
\text { Paxton } \\
\text { Pavant } \\
\text { Canyon Range } \\
\text { Wah Wah-Frisco }\end{array}$ & $\begin{array}{l}120 \text { total } \\
35 \\
15 \\
45 \\
25 \\
121 \text { total } \\
4 \\
27 \\
30 \\
50 \\
10\end{array}$ & $\begin{array}{c}(74) \\
(60,97) \\
(60,97) \\
(60,97) \\
(13,26,79,92) \\
(80) \\
(26,80) \\
(26,80) \\
(26,80) \\
(98)\end{array}$ \\
\hline $\begin{array}{l}\text { 5. Southeastern California and } \\
\text { southern Nevada } \\
\text { Spring Mountains } \\
\text { Keystone, Red Spring } \\
\text { (Wilson Cliffs-Contact) } \\
\text { Deer Creek } \\
\text { Lee Canyon } \\
\text { Wheeler Pass (Chicago Pass- } \\
\text { Winters Pass-Panamint) } \\
\text { Death Valley area } \\
\text { Clery (Lemoigne) } \\
\text { Marble Canyon (Schwaub Peak) } \\
\text { Last Chance }\end{array}$ & $\begin{array}{l}29.5 \\
5 \\
7.5\end{array}$ & $\begin{array}{c}(47,81,99) \\
(47) \\
(47)\end{array}$ \\
\hline
\end{tabular}

Vegas Valley region because few geological markers are present to allow estimation of the amount of extension directly and because extension is distributed between both high-strain and low-strain regions (Fig. 1). In order to place bounds on the total amount of extension in the northern Great Basin, we make use of paleomagnetic evidence from the Sierra Nevada that indicates little, if any, rotation of this block with respect to the extension direction since late Mesozoic time $(68-70)$. We assume on this basis that both the absolute magnitude and orientation of extension in the Great Basin remain constant from south to north. This implies that the percentage of extension decreases northward, from approximately $200 \%$ to $\sim 35 \%$ because the width of the province increases in that direction.

The overall extension in the northern Great Basin is resolved into two components, one associated with the high-strain region of eastcentral Nevada and adjacent areas (Fig. 1) and the other involving the entire width of the Great Basin. As a first approximation, we treat the two components as separate "events," although this treatment is probably not strictly correct (39). The direction of extension for the "earlier" event is inferred to be $295^{\circ}$ on the basis of a consistent pattern of sense of shear indicators and stretching lineations in several metamorphic core complexes $(20,21,37,71)$. Palinspastic reconstruction of the northern Egan, Schell Creek, and Snake ranges (E, SC, and $\mathrm{Sn}$ in Fig. 2) indicates that the minimum total extension is between $80 \mathrm{~km}$ and $\sim 95 \mathrm{~km}$ (or $250 \%$ ) across the high-strain region $(20,72)$. We assume that the higher figure is correct and attribute $72 \mathrm{~km}$ of this to the earlier extensional event, according to the assumptions of the reconstruction. "Later" extension across the entire Great Basin is computed as $176 \mathrm{~km}$ in the direction $284^{\circ}$. Of this $176 \mathrm{~km}, 23 \mathrm{~km}$ is associated with the highstrain region, and 3 to $7 \mathrm{~km}$ is restored east of the Wasatch fault [Fig. $2(73,74)]$. The inferred orientation for the later event is remarkably consistent with the orientation of both the modern stress field (38) and with the "transverse zones" defined by Stewart (75) between regions of contrasting structural tilt. No comparable reconstructions have been published for other transects across the high-strain region of east-central Nevada and environs, and the estimates of extension published by Gans and Miller (20) and Bartley and Wernicke (72) are assumed to be representative.

An approximation of the configuration of the highly extended region in the northern Great Basin is needed to reconstruct the positions of individual blocks. Borehole data from areas in which near-surface rocks are unmetamorphosed and beyond the principal exposures of the metamorphic core complexes indicate that highgrade metamorphic rocks are present at moderate depth and that the core complexes are distributed over a broader region than their outcrop pattern would suggest (37). The highly strained region is therefore assumed to be a continuous north-northeast-trending belt of approximately uniform width in which different crustal levels have been exposed by mid- to late Cenozoic extension (37). Boundaries of this region are placed between areas of low- to highgrade metamorphic rocks and unmetamorphosed strata or between areas of faulted and relatively unfaulted rocks and extrapolated to areas of limited control [Fig. $2(20,37)]$. For example, the Black Pine Mountains, just east of the metamorphic core complexes of the Albion, Raft River, and Grouse Creek ranges (BP, Al, RR, and GC in Fig. 2) contain strata metamorphosed to low grade bordered on the north and east by unmetamorphosed Paleozoic strata (37). These relations allow us to delineate approximately the northern and eastern limits of the high-strain region in southern Idaho. Immediately west of the metamorphic core complexes of the Egan and Cherry Creek ranges (E and CC in Fig. 2), the Butte Mountains are underlain by Paleozoic rocks that are both unfaulted and flat-lying (20) and are thus apparently west of the western boundary of the high-strain region. The highly extended belt continues southward 
and presumably connects with areas of similar extensional geology in the southern Great Basin, but its exact configuration is unknown.

Reconstruction of Mesozoic shortening. Estimates of the magnitude of shortening across the fold and thrust belt vary irregularly from north to south, but shortening was at least $104 \mathrm{~km}$ to $135 \mathrm{~km}$ (Table 1). The uncertainty is due in part to the absence of appropriate geological markers that can be matched across the faults. Few studies of mesoscopic kinematic indicators are available to determine the precise direction of shortening. Therefore regional east-directed transport, approximately perpendicular to the regional strike of thrust faults and parallel to the vergence direction of large-scale folds, is assumed to be representative $(11,24,76,77)$.

In detail, the magnitude of shortening appears to change along strike in the northern Great Basin. In the Idaho-Wyoming segment of the fold and thrust belt, an estimated $121 \mathrm{~km}$ of shortening is taken up on four major thrust systems [Table 1 and Figs. 2 and 3 (24)]. Shortening associated with individual thrust faults appears to decrease to the south to approximately $104 \mathrm{~km}$ in northern Utah [Table 1 and Figs. 2 and 3 (24)]. In the area north of Salt Lake City (SLC in Fig. 2), the Ogden duplex, a complex thrust system consisting of the Ogden, Weber, and Taylor thrust faults, is present in the lower plate of the older Willard thrust and accounts for $\sim 12$ $\mathrm{km}$ of additional shortening $(77,78)$. Imbricate thrust faults in basement-cored folds $(24,25,54)$ have been estimated to take up about $20 \mathrm{~km}$ of shortening. In central Utah, several thrust faults are exposed discontinuously in the deformed miogeoclinal wedge [Fig. $2(26,60)]$. The eastern limit of thrusting is not well known in this segment. Subsurface data indicate that blind faults are present east of the area in which such structures are exposed at the surface $(26,79$, 80 ). The magnitude of shortening is difficult to determine precisely owing to the lack of geological markers that can be matched across faults and to distributed deformation in Jurassic salt and shale but has been estimated to be approximately $120 \mathrm{~km}$ from balanced cross sections constrained by seismic and borehole data (Table 1 and Fig. 3).

The fold and thrust belt continues southward into southern Nevada and eastern California. Thrusting thought to be of mid- to late Cretaceous age in southern Nevada accommodates between 36 and $75 \mathrm{~km}$ of crustal shortening in the Spring Mountains block [Table 1 and Figs. 2 and $3(47,81)$ ]. On the basis of the fault correlations of Wernicke et al. (22), the only other major thrust fault west of the Spring Mountains and north of the Garlock fault that affects strata of Proterozoic and Early Cambrian age is the Last Chance thrust system. This fault system is considered to have been active during Triassic time $(11,49,53)$, and accounts for about 75 $\mathrm{km}$ of shortening, although this value is poorly constrained [Table 1 and Figs. 2 and $3(2,49,53,82)]$. Although the direction of tectonic transport appears to vary on a regional scale from east-southeast in southern Nevada to east-northeast in the Inyo Mountains [ $\mathrm{I}$ in Fig. $2(47,49,53,83)]$, these nuances are not included in the reconstruction.

Palinspastic reconstruction of the hinterland of the fold and thrust belt presents two difficulties. The first concerns the amount of additional crustal shortening there, which may be as much as several tens of kilometers but is nowhere well established $(8,57)$. In view of this uncertainty, and because there is not yet an objective way to assign known outcrops of Proterozoic and Lower Cambrian rocks to any particular thrust sheet on a regional scale, we have chosen not to include hinterland deformation in the reconstruction. The second difficulty concerns the origin of an apparent eastward bend in Paleozoic lithofacies trends, the Antler orogenic belt, and the 0.706 line in northeastern Nevada. We favor the original interpretation of Roberts et al. (34) that this bend represents a primary irregularity in the continental margin and in the geometry of the orogen. Our reconstruction therefore differs in this regard from that of Stewart and Poole (2), who interpreted this bend as an oroflexural feature affecting a broad region as far east as western Wyoming. A third interpretation, that the change in trend might be related to right slip during Mesozoic time on the hypothetical Wells fault (84), appears unlikely because supposed offsets of Paleozoic facies belts are inconsistent with each other (85). Moreover, none of the evidence cited for the existence of the Wells fault adequately accounts for the effects of either Mesozoic thrusting (86) or Cenozoic extension. We have therefore chosen not to incorporate this speculative feature in our reconstruction.

Reconstruction of the $\mathrm{I}_{S r}=0.706$ isopleth. The close conformity of the 0.706 line for rocks of wide compositional and age ranges implies a relatively fixed spatial arrangement between the respective crustal and mantle magma sources since the Mesozoic (87). We therefore assume that the basal detachment for the Cordilleran fold and thrust belt is rooted at mantle depths in central Nevada and restore the 0.706 line for the maximum amount of Mesozoic crustal shortening (Fig. 3). Cenozoic extension is restored according to the assumptions discussed above.

\section{Errors in the Reconstruction}

Our reconstruction is subject to a number of uncertainties. The most significant are (i) the magnitude and direction of Cenozoic extension determined in the southern Great Basin; (ii) the amount of rotation experienced by the Sierra Nevada; (iii) the location of the boundaries of the highly strained region in the northern Great Basin; and (iv) the use of minimum estimates of shortening in the fold and thrust belt.

Cenozoic extension in the southerm Great Basin. The magnitude and direction of extension estimated in the southern Great Basin $\left(247 \pm 56 \mathrm{~km}, 287^{\circ} \pm 12^{\circ}\right)$ are from the work of Wernicke et al. (22). Uncertainties, quoted at the $95 \%$ confidence level, are based on statistical analysis of geological errors primarily having to do with the correlation of thrust faults and associated structures. The analysis of Wernicke et al. (22) is the most complete available but is not wholly accepted in detail $(83,88,89)$. For example, central to their reconstruction is the interpretation of the Wheeler Pass, Chicago Pass, Winters Pass, and Panamint thrusts as segments of the same fault now widely separated in extensional fault blocks. If these thrust faults are not the same, the inferred amount of extension is probably overestimated and the amount of shortening underestimated.

Another possible problem concerns the location of the breakaway zone for the Death Valley fault system. In the reconstruction of Wernicke et al. (22), this breakaway zone is placed immediately to the west of the Spring Mountains, and the Wheeler Pass thrust is assumed to have an approximately north-south pre-extension orientation. Although it is mechanically reasonable to assume that the footwall of a detachment fault would be elevated isostatically (the Spring Mountains), direct geological evidence cannot exclude the possibility that the breakaway is actually located as much as $20 \mathrm{~km}$ farther west beneath the adjacent Pahrump Valley and that the Wheeler Pass thrust had a more curvilinear pre-extension configuration. This alternative geometry would also reduce the amount of extension inferred.

Although we have accepted the overall extension direction estimated by Wernicke et al. (22) as the most reasonable approximation, in detail the motion of individual blocks may have varied in both time and space, and the reconstruction may thus locally juxtapose inconsistent geology. For example, the Kingston Range (KR in Fig. 2) appears to have been extended toward the southwest, nearly 
perpendicular to the regional extension direction (89).

Rotation of the Sierra Nevada. Integral to our reconstruction of Cenozoic extension in the northern Great Basin is paleomagnetic evidence from Cretaceous plutons and Jurassic wall rocks (68-70) for little or no rotation of the Sierra Nevada with respect to the extension direction since late Mesozoic time. The best constraint, an apparent clockwise rotation of $6^{\circ} \pm 8^{\circ}$, is provided by Frei (70). In contrast, Hamilton $(90)$ has proposed on the basis of tectonic analysis that extension across the entire Great Basin was as much as $100 \%$ at all latitudes (that is, a greater absolute magnitude of extension in the north than in the south). This interpretation implies that during the Cenozoic the Sierra Nevada rotated between $20^{\circ}$ to $30^{\circ}$ in a counterclockwise direction relative to the Colorado Plateau.

The paleomagnetic evidence from the Sierra Nevada, especially that of Frei (70), is discounted by Hamilton (90) on several grounds. First, the paleomagnetic data were corrected only for late Neogene westward tilting of the range. Hamilton argues that the Sierra Nevada batholith has been eroded $5 \mathrm{~km}$ or so deeper in the west than in the east as a result of earlier tilting toward the east and that the small clockwise rotation determined by Frei should be reduced by about $5^{\circ}$. We have not incorporated this correction because the magnitude of differential uplift is poorly constrained and may have been accomplished in part by faulting rather than simple tilting. We also note that the removal of eastward tilting would actually lead one to infer greater rather than smaller clockwise rotation of the batholith. A second criticism made by Hamilton is that Frei (70) did not correct her results for clockwise rotation of the Colorado Plateau of about $8^{\circ}$ since mid-Cretaceous time. If this interpretation is correct, it implies that the Sierra Nevada rotated counterclockwise with respect to the Colorado Plateau by approximately $-2^{\circ} \pm 8^{\circ}$. A final criticism concerns uncertainties in the age of magnetization and especially in the position of the North American reference pole during Cretaceous time. A recent reevaluation of the mid-Cretaceous reference pole, including new data from intrusive rocks in Arkansas (91), suggests that the Sierra Nevada may have rotated counterclockwise by as much as an additional $9^{\circ}$ for a total rotation of $-11^{\circ}$. The effect of this possible systematic error is considered below.

The uncertainty in the magnitude of Cenozoic extension in the northern Great Basin can be quantified by combining the uncertainties in the amount of extension in the southern Great Basin with those associated with the rotation of the Sierra Nevada. In the reconstruction we have assumed $0^{\circ}$ rotation of the Sierra Nevada, an estimate which falls within Frei's paleomagnetically determined limits. We make the simplifying assumption that for any rotation the change in azimuth of the southern part of the Sierra Nevada is the same as at the paleomagnetic sampling sites. We also assume that the Sierra Nevada rotated as a rigid block because a comparison of paleomagnetic results at two localities that are $\sim 150 \mathrm{~km}$ apart suggests that there has been no internal deformation ( $95 \%$ confidence level) $(70)$. A counterclockwise rotation of $10^{\circ}\left(-2^{\circ}-8^{\circ}\right)$ increases the amount of extension across the northern Great Basin at the latitude of $40^{\circ} \mathrm{N}$ in eastern California by $92 \mathrm{~km}$ in the direction of extension, whereas a clockwise rotation of $6^{\circ}$ decreases the extension by $72 \mathrm{~km}$. We use a root mean square approximation to combine the paleomagnetically derived uncertainties in extension $\left({ }_{-72}^{+92} \mathrm{~km}\right)$ with those derived from geological constraints in the southern Great Basin $( \pm 56 \mathrm{~km})$ to obtain an uncertainty in the extension of the northern Great Basin of ${ }_{-91}^{+108} \mathrm{~km}$ at the $95 \%$ confidence level. The limit to clockwise rotation is consistent with geological data. In the northern Great Basin there was at least $95 \mathrm{~km}$ total extension in the highly strained region (20), 35 to $40 \mathrm{~km}$ extension between the highly strained belt and the Colorado Plateau
$(92,93)$, and at least $30 \mathrm{~km}$ extension in western Nevada (94), giving a minimum estimate of $160 \mathrm{~km}$ for the entire region. This limits the range of overall extension at $40^{\circ} \mathrm{N}$ in the northern Great Basin to $247+{ }_{-87}^{+108} \mathrm{~km}$. The level of uncertainty increases northward as the component of the error introduced by the rotation of the Sierra Nevada increases to the north. Uncertainty in the position of the reference pole leads to a systemic error that is difficult to assess. Use of the reference pole of Globerman and Irving (91) would permit as much as $65 \mathrm{~km}$ of additional extension.

Boundaries of the highly strained region. In the northern Great Basin, uncertainties in the position of the boundaries of the highly strained region do not produce large uncertainties in the reconstruction of individual blocks. Blocks to the east of the highly strained region were not affected by the "earlier" extension event, whereas rocks to the west of this region experienced the total amount of earlier extension (Fig. 3). Rocks in this belt experienced a proportion of the total extension, which is sensitive both to the width of the belt and the distance of a given locality from the boundaries of the belt. However, if the boundaries are relocated such that the width of the highly strained region or the distance of a block from the boundaries changes by as much as a few tens of kilometers, the difference in magnitude of extension experienced by an individual block is typically $<5 \mathrm{~km}$. Thus, although the boundaries of this region may not be located precisely, they do not affect the reconstruction critically at the scale of the reconstruction.

Shortening in the fold and thrust belt. Another uncertainty is introduced into the reconstruction by the use of minimum values for crustal shortening. In many cases, diagnostic stratigraphic markers cannot be matched between upper and lower plates of a particular fault, and in the absence of appropriate cross-sections, assessment of the amount of shortening taken up by folding is difficult. In southern Idaho and northern Utah, most of the exposed middle Proterozoic through Lower Cambrian rocks are west of the fold and thrust belt, and the relative positions of blocks are insensitive to errors in the estimation of shortening on any particular structure. In central Utah, a small number of outcrops have been affected by some but not all of the major thrust faults, and the relative positions of these outcrops are subject to errors that cannot be quantified with available data. In the southern Great Basin, thrust faulting extended well into the miogeocline, and the most significant errors are likely to be present there. Although the relative positions of blocks are little affected by uncertainties in shortening along east-west transects, north-south positioning is less firm because it is subject to varying estimates of the shortening at different positions along the fold and thrust belt.

\section{Applications and Evaluation of the Reconstruction}

An important application of the reconstruction, and indeed our reason for undertaking the work, is in unraveling the late Proterozoic and Early Cambrian evolution of the western United States. It is now possible to analyze regional facies relations and to portray paleogeography on an appropriate base map (95). Mesozoic crustal shortening and Cenozoic extension are generally in opposite directions but do not even approximately cancel each other out (Fig. 3). Relative positions of blocks in the reconstruction are generally similar to their present positions, but distances between blocks are in some cases substantially different from those of the present day, especially in the highly extended regions of eastern Nevada and eastern California (compare Figs. 2 and 3). The original width of the preserved part of the basin (estimated from the 0.706 line to the approximate eastern edge of thick late Proterozoic strata) was about 
150 to $300 \mathrm{~km}$, or about $60 \%$ of its present width, and the basin was oriented slightly more north-south with respect to present-day coordinates. The irregular configuration of the 0.706 line, slightly straightened in the reconstruction, is interpreted to reflect extensional and transform segments of the early Paleozoic continental margin. The precise configuration of the eastern limit of thick late Proterozoic strata is largely an artifact of thrust-fault geometry (Figs. 2 and 3), but in some cases this boundary is demonstrably related to the location of the basin edge. An example is the contrasting late Proterozoic geology of the upper and lower plates of the Willard thrust in northern Utah (5), still in close proximity in the reconstruction.

Another application of the reconstruction is in the interpretation of Paleozoic geology, particularly to study the subsidence history of the passive continental margin in two dimensions and hence to place additional constraints on distribution of extension in the lithosphere immediately before development of the continental margin. Earlier analyses have been confined to isolated localities by the lack of an appropriate palinspastic base map [for example, $(3,5,31)$ ]. For this purpose, the reconstruction needs to be modified to take into account the different relations of Proterozoic and Paleozoic rocks with respect to major structures.

The reconstruction also needs to be evaluated critically, especially in the areas of greatest geological complexity. For example, in both eastern Nevada and the southern Great Basin, extensional fault blocks that are now widely separated are brought into close proximity in the reconstruction. To what extent is the reconstruction consistent with the geology of these blocks? Regional crosssections are needed to attempt more sophisticated analysis of structural evolution, and more attention should be given to the kinematics of deformation. Improved paleomagnetic constraints would be helpful, particularly better documentation of the late Mesozoic polar wander path for North America.

\section{REFERENCES AND NOTES}

1. J. H. Stewart, Geol. Soc. Am. Bull. 83, 1345 (1972).

2. and F. G. Poole, Soc. Econ. Paleontol. Mineral. Spec. Publ. 22 (1974), p. 28.

3. R. A. Armin and L. Mayer, Geology 11, 702 (1983); G. C. Bond, M. A. Kominz, W. J. Devlin, Nature 306, 775 (1983).

4. G. C. Bond, M. A. Kominz, J. P. Grotzinger, in New Perspectives in Basin Analysis, K. L. Kleinspehn and C. Paola, Eds. (Springer-Verlag, New York, 1988), pp. 129-160.

5. N. Christie-Blick and M. Levy, in Late Proterozoic and Cambrian Tectonics, Sedimentation, and Record of Metazoan Radiation in the Western United States, $\mathbf{N}$. Christie-Blick and M. Levy, Eds. (Field Trip Guidebook T331, American Geophysical Union, Washington, DC, 1989), pp. 7-21.

6. M. Kay and J. P. Crawford, Geol. Soc. Am. Bull. 75, 425 (1964); T. H. Nilsen and J. H. Stewart, Geology 8, 298 (1980).

7. R. C. Speed and N. H. Sleep, Geol. Soc. Am. Bull. 93, 815 (1982).

8. R. Speed, M. W. Elison, F. R. Heck, in Metamorphism and Crustal Evolution of the Westem United States, W. G. Ernst, Ed. (Rubey Vol. VII, Prentice-Hall, Englewood Cliffs, NJ, 1988), pp. 572-605.

9. F. C. Armstrong and S. S. Oriel, Bull. Am. Assoc. Petrol. Geol. 49, 1847 (1965).

10. R. L. Armstrong, Geol. Soc. Am. Bull. 79, 1295 (1968).

11. B. C. Burchfiel and G. A. Davis, in The Geotectonic Development of Califomia, W. G. Ernst, Ed. (Rubey Vol. I, Prentice-Hall, Englewood Cliffs, NJ, 1981), pp. $217-$ 252.

12. R. A. Price, Geol. Soc. London Spec. Publ. 9, 427 (1981).

13. R. W. Allmendinger, in Cordilleron Orogen: U.S., B. C. Burchfiel, P. W. Lipman, M. L. Zoback, Eds. (Geological Society of America, Denver, in press).

14. P. Misch and J. C. Hazzard, Bull. Am. Assoc. Petrol. Geol. 46, 289 (1962).

15. R. E. Anderson, Geol. Soc. Am. Bull. 82, 43 (1971); B. P. Wernice, Can. J. Earth Sci. 22, 108 (1985)

16. R. L. Armstrong, Geol. Soc. Am. Bull. 83, 1729 (1972).

17. J. H. Stewart, Geol. Soc. Am. Mem. 152 (1978), p. 1.

18. M. D. Crittenden, Jr., P. J. Coney, G. H. Davis, Eds., Geol. Soc. Am. Mem 153 (1980).

19. G. P. Eaton, Annu. Rev. Earth Planet. Sci. 10, 409 (1982).

20. P. B. Gans and E. L. Miller, Utah Geol. Mineral Surv. Spec. Stud. 59, 107 (1983).

21. E. L. Miller, P. B. Gans, J. E. Wright, J. F. Sutter, in Metamorphism and Crustal Evolution of the Westerm United States, W. G. Ernst, Ed. (Rubey Vol. VII, PrenticeHall, Englewood Cliffs, 1988), pp. 649-682.
22. B. Wernicke, G. J. Axen, J. K. Snow, Geol. Soc. Am. Bull. 100, 1738 (1988).

23. G. M. Kay, Bull. Geol. Soc. Am. 48, 232 (1937). The term "palinspastic" (from the Greek word meaning stretched back) was coined by Kay (p. 291) to refer to the repositioning of deformed Paleozoic sedimentary rocks to account for the effects of thrust faulting.

24. F. Royse, Jr., M. A. Warner, D. L. Reese, in Symposium on Deep Drilling Frontiers in the Central Rocky Mountains, D. W. Bolyard, Ed. (Rocky Mountain Association of Geologists, Denver, 1975), pp. 41-54.

25. R. B. Smith and R. L. Bruhn, J. Geophys. Res. 89, 5733 (1984).

26. A. Villien and R. M. Kligfield, Am. Assoc. Petrol. Geol. Mem. 41 (1986), p. 281.

27. R. W. Allmendinger et al., Geol. Soc. Am. Bull. 98, 308 (1987).

28. R. L. Armstrong, Utah Geol. Mineral. Surv. Bull. 78 (1968).

29. K. A. Plumb and H. L. James, Precamb. Res. 32, 65 (1986).

30. W. B. Harland et al., Geologic Timescale 1989 (Cambridge Univ. Press, New York, 1989).

31. G. C. Bond, N. Christie-Blick, M. A. Kominz, W. J. Devlin, Nature 316, 742 (1985).

32. M. D. Crittenden, Jr., J. H. Stewart, C. A. Wallace, 24th Int. Geol. Congr. Sec. 1 (1972), p. 334; L. A. Wright, B. W. Troxel, E. G. Williams, M. T. Roberts, P. E. Diehl, Calif. Div. Mines Geol. Spec. Rep. 106 (1976), p. 7; J. H. Stewart, in Geology of Selected Areas in the San Bemardino Mountains, Western Mojave Desent, and Southem Great Basin, Califomia, J. D. Cooper, B. W. Troxel, L. A. Wright, Eds. (Geol. Soc. Am. Cordilleran Sect. Meeting Guidebook, Death Valley Publishing, Shoshone, ID, 1982), pp. 171-186.

33. W. R. Dickinson, in The Geotectonic Development of Califormia, W. G. Ernst, Ed (Rubey Vol. I, Prentice-Hall, Englewood Cliffs, NJ, 1981), pp. 1-28.

34. R. J. Roberts et al., Bull. Am. Assoc. Petrol. Geol. 49, 1926 (1965).

35. C. F. Kuth and P. J. Coney, Geology 9, 10 (1981).

36. R. W. Allmendinger and T. E. Jordan, ibid., p. 308

37. A. W. Snoke and D. M. Miller, in Metamorphism and Crustal Evolution of the Westem United States, W. G. Ernst, Ed. (Rubey Vol. VII, Prentice-Hall, Englewood Cliffs, NJ, 1988), pp. 606-648.

38. M. L. Zoback, R. E. Anderson, G. A. Thompson, Philos. Trans. R. Soc. London Ser. A 300, 407 (1981).

39. B. P. Wernicke, R. L. Christiansen, P. C. England, L. J. Sonder, Geol. Soc. London Spec. Publ. 22, 203 (1987).

40. $I_{\mathrm{Sr}}$ refers to the initial ${ }^{87} \mathrm{Sr} /{ }^{86} \mathrm{Sr}$ ratio.

41. R. W. Kistler and Z. E. Peterman, Geol. Soc. Am. Bull. 84, 3489 (1973); U.S. Geol. Surv. Prof. Pap. 1071 (1978).

42. R. W. Kistler and D. E. Lee, U.S. Geol. Surv. Open-File Rep. 89-199 (1989).

43. G. L. Farmer and D. J. DePaolo, J. Geophys. Res. 88, 3379 (1983); G. L. Farmer, in Metamorphism and Crustal Evolution of the Westerm United States, W. G. Ernst, Ed. (Rubey Vol. VII, Prentice-Hall, Englewood Cliffs, NJ, 1988), pp. 87109; G. L. Farmer, Geol. Soc. Am. Abstr. Progr. 21, 77 (1989).

44. K. D. Ehman, thesis, University of California, Davis (1985).

45. P. J. Coney and T. H. Harms, Geology 12, 550 (1984); P. J. Coney, Geol. Soc. London Spec. Publ. 22 (1987), p. 177; L. J. Sonder, P. C. England, B. P. Wernicke, R. L. Christiansen, ibid., p. 187.

46. P. B. King, U.S. Geol. Surv. Prof. Pap. 628 (1969).

47. B. C. Burchfiel, R. J. Fleck, D. T. Secor, R. R. Vincelette, G. A. Davis, Geol. Soc Am. Bull. 85, 1013 (1974).

48. S. S. Oriel and F. C. Armstrong, Bull. Am. Assoc. Petrol. Geol. 50, 2614 (1966).

49. G. C. Dunne, R. M. Gulliver, A. G. Sylvester, in Mesozoic Paleogeography of the Westem United States, D. G. Howell and K. A. McDougall, Eds. (Pac. Coast Paleogeogr. Symp. 2, Society of Economic Paleontologists and Mineralogists, Los Angeles, 1978), pp. 189-207.

50. T. E. Jordan, Am. Assoc. Petrol. Geol. Bull. 65, 2506 (1981)

51. P. R. Lamerson, in Geologic Studies of the Cordilleran Thrust Belt, R. B. Powers, Ed. (Rocky Mountain Association of Geologists, Denver, 1982), pp. 279-340.

52. D. V. Wiltschko and J. A. Dorr, Jr., Am. Assoc. Petrol. Geol. Bull. 67, 1304 (1983).

53. K. Corbett, C. T. Wrucke, C. A. Nelson, in This Extended Land, Geological Joumeys in the Southem Basin and Range, D. L. Weide and M. L. Faber, Eds. (Geol. Soc. Am. Cordilleran Sect. Field Trip Guide, University of Nevada, Las Vegas, 1988), pp. 269-292.

54. R. L. Bruhn, M. D. Picard, J. S. Isby, Am. Assoc. Petrol. Geol. Mem. 41, 333 (1986).

55. T. A. Cross, Spec. Publ. Int. Assoc. Sedimentol. 8, 15 (1986).

56. R. W. Allmendinger and L. B. Platt, Geol. Soc. Am. Mem. 157 (1983), p. 149.

57. J. M. Bartley, J. B. Matulevich, G. G. Gleason, Geol. Soc. Am. Abstr. Progr. 19 581 (1987); D. L. Smith, thesis, Stanford University, Stanford, CA (1989).

58. P. L. Heller et al., Geology 14, 388 (1986).

59. R. J. Fleck, Geol. Soc. Am. Bull. 81, 1705 (1970).

60. H. T. Morris, Geol. Soc. Am. Mem. 157 (1983), p. 75

61. P. L. Guth, Geol. Soc. Am. Bull. 92,763 (1981).

62. B. Wernicke, J. E. Spencer, B. C. Burchfiel, P. L. Guth, Geology 10, 499 (1982)

63. I. Cemen, L. A. Wright, R. E. Drake, F. C. Johnson, Soc. Econ. Paleontol. Mineral. Spec. Publ. 37 (1985), p. 127

64. J. H. Stewart, Geology 11,153 (1983).

65. R. G. Bohannon, in Cenozoic Paleogeography of the Westem United States, J. M. Armentrout, M. R. Cole, H. Terbest, Jr., Eds. (Pac. Coast Paleogeogr. Symp. 3 Society of Economic Paleontologists and Mineralogists, Los Angeles 1979), pp. 129-139; U.S. Geol. Surv. Prof. Pap. 1259 (1984).

66. C. R. Longwell, Am. J. Sci. 258-A, 192 (1960); J. C. Osmond, Bull. Am. Assoc Petrol. Geol. 46, 2033 (1962); R. J. Ross, Jr., and C. R. Longwell, U.S. Geol. Surv. Bull. 1180-C, C88 (1964); B. C. Burchfiel, Geol. Soc. Am. Bull. 76, 175 (1965); F. G. Poole et al., in Intemational Symposium on the Devonian System, Calgary, Alberta, September 1967, vol. 1, D. H. Oswald, Ed. (Alberta Society of 
Petroleum Geologists, Calgary, Alberta, 1967); J. H. Stewart, Geol. Soc. Am. Bull. 78, 131 (1967); J. H. Stewart, J. P. Albers, F. G. Poole, ibid. 79, 1407 (1968).

67. R. E. Anderson, U.S. Geol. Surv. Prof. Pap. 794 (1973).

68. L. S. Frei, J. R. Magill, A. Cox, Tectonics 3, 157 (1984); N. L. Bogen, D. V. Kent, R. A. Schweickert, J. Geophys. Res. 90, 4627 (1985).

69. N. L. Bogen and R. A. Schweickert, Earth Planet. Sci. Lett. 75, 93 (1985).

70. L. S. Frei, Geol. Soc. Am. Bull. 97, 840 (1986).

71. A. W. Snoke and A. P. Lush, in Westem Geological Excursions, J. Lintz, Jr., Ed. (Field Trip Guidebook, Mackay School of Mines, Reno, 1984), vol. 4, Pp. 232260; S. L. Wust, Geology 14, 828 (1986).

72. J. M. Bartley and B. P. Wernicke, Tectonics 3, 647 (1984).

73. J. S. Dixon, Am. Assoc. Petrol. Geol. Bull. 66, 1560 (1982).

74. R. L. Bruhn, personal communication.

75. J. H. Stewart, Geol. Soc. Am. Bull. 91, 460 (1980)

76. C. D. A. Dahlstrom, Bull. Can. Petrol. Geol. 18, 332 (1970); S. E. Boyer and D. Elliott, Am. Assoc. Petrol. Geol. Bull. 66, 1196 (1982); E. W. Tooker, Geol. Soc. Am. Mem. 157 (1983), p. 61.

77. M. D. Crittenden, Jr., Geol. Soc. Am. Bull. 83, 2871 (1972).

78. T. W. Schirmer, in Orogenic Patterms and Stratigraphy of North-Central Utah and Southeasterm Idaho, G. J. Kerns and R. L. Kerns, Jr., Eds. (Publ. 14, Utah Geological Association, Salt Lake City, 1985), pp. 129-143; T. W. Schirmer, Am. Assoc. Petrol. Geol. Bull. 72,573 (1988).

79. L. A. Standlee, in Geologic Studies of the Cordilleran Thrust Belt, R. B. Powers, Ed. (Rocky Mountain Association of Geologists, Denver, 1982), pp. 357-382; R. W. Allmendinger et al., in Reflection Seismology: The Continental Crust, M. Barazangi and L. Brown, Eds. (Geodynam. Ser. 14, American Geophysical Union, Washington, DC, 1986), pp. 257-268.

80. F. Royse, personal communication.

81. G. J. Axen, Geol. Soc. Am. Bull. 95, 1202 (1984)

82. J. H. Stewart et al., U.S. Geol. Surv., Prof. Paper 55-D (1966), p. D-23.

83. K. Corbett, personal communication.

84. F. G. Poole, C. A. Sandberg, A. J. Boucot, in Paleozoic Paleogeography of the Westem United States, J. H. Stewart, C. H. Stevens, A. E. Fritsche, Eds. (Pac. Coast Paleogeogr. Symp. 1, Society of Economic Paleontologists and Mineralogists, 1977), pp. 39-65; C. H. Thorman and K. B. Ketner, in 1979 Basin and Range Symposium, G. W. Newman and H. D. Goode, Eds. (Rocky Mountain Association of Geologists, Denver, 1979), pp. 123-133.

85. C. H. Stevens, Geology 9, 534 (1981).

86. R. R. Coats and J. F. Riva, Geol. Soc. Am. Mem. 157 (1983), p. 305.

87. W. P. Leeman, J. S. Oldow, W. K. Hart, Geol. Soc. Am. Abstr. Progr. 21, 105 (1989).

88. A. R. Prave, personal communication.

89. B. C. Burchfiel, personal communication.

90. W. Hamilton, in Metamorphism and Crustal Evolution of the Wester United States, W. G. Ernst, Ed. (Rubey Vol. VII, Prentice-Hall, Englewood Cliffs, 1988), pp. 1-40.
91. B. R. Globerman and E. Irving, J. Geophys. Res. 93, 11,721 (1988).

92. J. W. Sharp, thesis, Cornell University, Ithaca, NY (1974).

93. D. B. von Tish, R. W. Allmendinger, J. W. Sharp, Am. Assoc. Petrol. Geol. Bull. 69, 1077 (1985).

94. T. A. Hauge et al., Geol. Soc. Am. Bull. 98, 320 (1987)

95. N. Christie-Blick and M. Levy, Geol. Soc. Am. Abstr. Progr. 20, 150 (1988).

96. The configuration of the Crawford thrust at depth is uncertain. In cross sections by Royse et al. (24), the Crawford thrust merges with the Willard thrust at depth. In this case, the lower value of displacement on the Willard thrust in the Salt Lake City-Ogden area $(35 \mathrm{~km})$, which includes the displacement on the Crawford thrust, is due to decreasing displacement southward (74). If the Crawford thrust does not merge with the Willard thrust at depth, it is then assumed to die out into basement imbrications in the Farmington Canyon complex. In this case, shortening on basement imbricates $(\sim 20 \mathrm{~km})$ plus shortening on the Willard thrust (35 $\mathrm{km}$ ) is approximately equivalent to the amount of shortening on the Willard and Crawford thrusts in northern Utah $(51 \mathrm{~km})$ [W. A. Yonkee, W. T. Parry, R. L. Bruhn, P. H. Cashman, Geol. Soc. Am. Bull. 101, 304 (1989)]

97. N. Blick, thesis, University of California, Santa Barbara (1979)

98. On the basis of stratigraphic separation.

99. B. C. Burchfiel and G. A. Davis, in This Extended Land, Geological Jourmeys in the Southem Basin and Range, D. L. Weide and M. L. Faber, Eds. (Geological Society of America, Cordilleran Sect. Field Trip Guide, University of Nevada, Las Vegas, 1988), pp. 87-106.

100. J. K. Snow, personal communication.

101. J. G. Bond, Geologic Map of Idaho, 1:500,000 (Idaho Department of Lands, Bureau of Mines and Geology, Moscow, 1978); J. D. Love and A. C. Christiansen, Geologic Map of Wyoming, 1:500,000, (Geologic Survey of Wyoming, Laramie, 1985); L. F. Hintze, Geologic Map of Utah, 1:500,000 (Utah Geological and Mineral Survey, Salt Lake City, 1980); J. H. Stewart and J. E. Carlson, Geologic Map of Nevada, 1:500,000 (U.S. Geological Survey, Reston, 1978); C. W. Jennings, R. G. Strand, T. H. Rogers, Geologic Map of Califormia, 1:750,000 (California Division of Mines and Geology, Sacramento, 1977); J. H. Stewart, Nevada Bureau of Mines and Geology Spec. Publ. 4 (1980).

102. This research was supported by grants from the National Science Foundation (EAR 85-17923) and the Donors of the Petroleum Research Fund, administered by the American Chemical Society (PRF 16042-G2 and PRF 19989-AC2), and by the Arthur D. Storke Memorial Fund of the Department of Geological Sciences, Columbia University. We thank many scientists who freely shared their ideas, expertise, and much unpublished data, especially R. W. Allmendinger, $R$. L. Bruhn, B. C. Burchfiel, K. Corbett, G. C. Dunne, G. L. Farmer, P. L. Guth, R. M. Kligfield, L. B. McCollum, D. M. Miller, A. R. Prave, F. Royse, J. K. Snow, B. P. Wernicke, and C. T. Wrucke. We also thank M. H. Anders, W. Hamilton, P. E. Olsen, R. W. Schlische, J. H. Stewart, and B. P. Wernicke for critically reviewing the manuscript. Working copies of the maps at a scale of $1: 2,000,000$ may be obtained from the authors at the cost of reproduction. Lamont-Doherty Geological Observatory Contribution No. 4506.

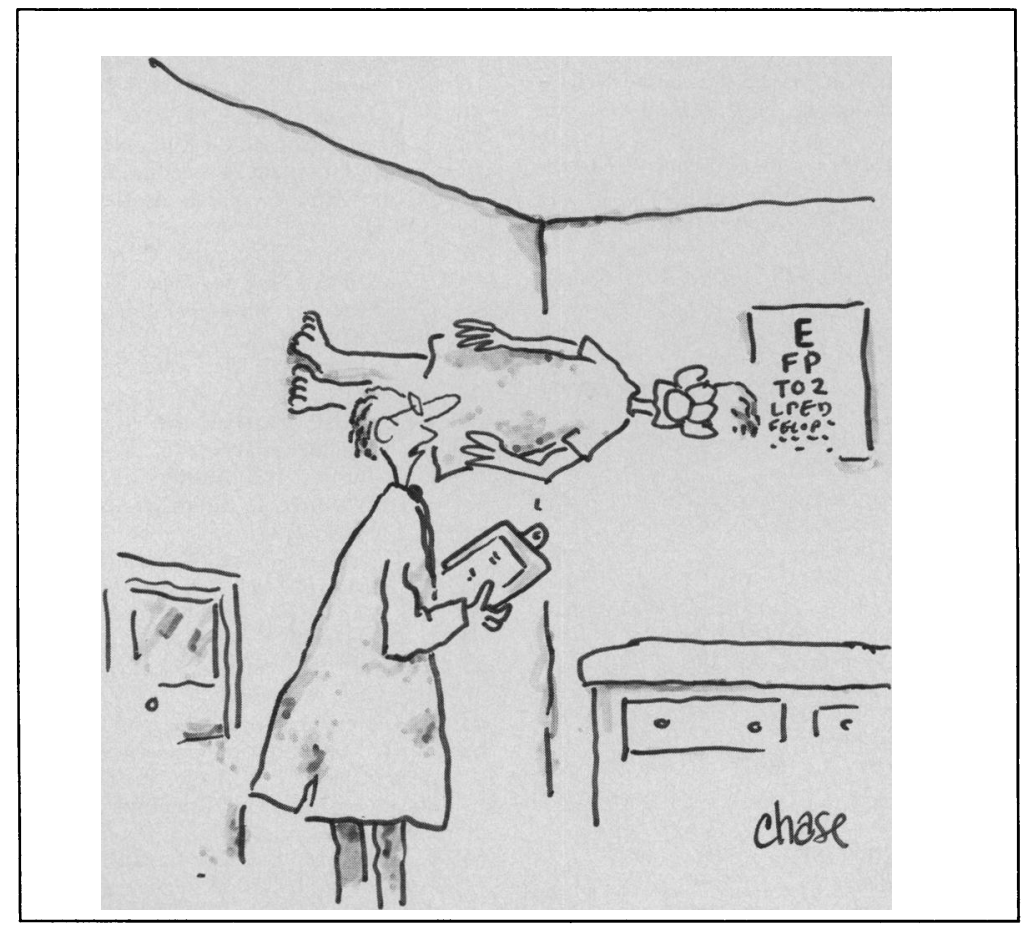

"You have an inner ear disorder." 